\title{
Book Review: Peter Berglez Global journalism: Theory and practice
}

\section{Ojala, Markus}

2014

Ojala , M 2014 , ' Book Review: Peter Berglez Global journalism: Theory and practice ' , Journalism , vol. 15 , no. 4 , pp. 504-505 .<

http://jou.sagepub.com/content/15/4/504.full.pdf+html >

http://hdl.handle.net/10138/337692

submittedVersion

Downloaded from Helda, University of Helsinki institutional repository.

This is an electronic reprint of the original article.

This reprint may differ from the original in pagination and typographic detail.

Please cite the original version. 
Peter Berglez

Global Journalism: Theory and Practice

New York: Peter Lang, 2013. 156 pp. ISBN 978-1-4331-1030-6

Reviewed by Markus Ojala, University of Helsinki

Email: markus.ojala@helsinki.fi

In Global Journalism: Theory and Practice, Peter Berglez voices a forceful call for mainstream news journalism to adopt more globalized practices of source selection, narration and framing. The global journalism Berglez proposes points to ways in which a news story can create awareness of global interdependences by connecting the reported event with developments in distant locations or with broader global processes. Only through such paradigmatic shift toward more global outlooks can news journalism remain relevant in a globalized society and serve its democratic functions, Berglez claims.

The book outlines the needed cognitive, discursive and epistemic change in journalism through five chapters. The first two introduce the basic argument and spell out the book's conception of what global journalism actually is as a reporting practice and news style. Here Berglez associates global journalism both conceptually and historically with the processes of globalization: it is the increasing transnational connections in all spheres of social life, and the consequent blurring of local and national boundaries, that should increasingly be represented in journalistic reporting. It implies the mainstreaming of such news practices that intentionally draw connections between local events and global phenomena, such as climate change, pandemics, crime and business.

It is the kind of reporting that observes its subject within a context of multiple spaces, powers and identities, rather than sticking to narrow local or national frames of reference as the news normally does. Moreover, instead of forming a separate news genre alongside domestic, foreign and business news, Berglez wants us to regard global journalism as a particular feature of reporting, potentially permeating all kinds of news journalism - even local news. All news reporters need to do is to cease their habitual practices of disconnecting the events they are reporting on from their global relations.

Chapters three and four discuss the promises of and challenges to the proposed shift in news practices. Berglez argues that the construction and dissemination of increasingly global outlooks in reporting could help news journalism regain its social relevance. By increasing the news audiences' awareness of the complex global interdependences and power relations, global journalism can reproduce globalization "from below" and foster democratic participation in national and transnational political processes. And while refraining from outlining any concrete business models, Berglez even suggests that global journalism should be considered as one of the solutions to the current crisis of journalism.

But before global journalism can save both news business and democracy, it must overcome some stubborn resistance posed against it by the continuing grip of national discourses and cognitive frames of reference, as well as by the habitual news practices sedimented over the course journalism's professional institutionalization within the context of the nation-state. These challenges can only be addressed through concerted education of journalists and their retraining into more reflexive practices of reporting.

The book's final chapter discusses how global journalism can and should operate in online environments, constituting a practice that both protects the authority and relevance of journalism in the global age and integrates a plurality of perspectives into its reporting so as to foster democratic participation. In this regard, Berglez highlights hyperlinks as particularly useful tools for the construction of global outlooks in online environments.

Global Journalism: Theory and Practice works as a welcome conceptual opening and marks a refreshingly 
ambitious attempt to start a new discourse in journalism research, practice and education. Central arguments are clear and repeated throughout the text, which makes the book highly accessible to students, researchers and practitioners alike. Berglez provides useful conceptual tools for the analysis of actual news texts and offers some illustrative cases of global journalism from Swedish newspapers. However, more analytical examples of how global outlooks operate in different news genres would have been welcome. Particularly the book's discussion on the differences between business journalism and "extra-economic" journalism would have benefited from concrete illustrations.

Unfortunately, there is at times a somewhat sketchy and unedited feel to the book with some hastily written passages and unelaborated argumentation. The theoretical foundation of global journalism, for instance, is laid out in terms of a rather unsatisfactory and overly simplified discussion on the materialdiscursive "reality" of globalization, and the bold claims concerning the empowering and democratizing effects of the envisioned new journalistic practices remain thinly justified at best. There is also some confusing oscillation throughout the book with regard to the normative and ideological bases of global journalism, particularly in its relationship with cosmopolitan and left-wing worldviews. But while such deficiencies take some force out of the most utopian claims, the overall argument Berglez makes for global journalism is highly commendable and should attract widespread attention within the field. Surely the theoretical and normative contours of global journalism, as well as its actual journalistic practices, become more clearly demarcated as the debate moves forward. 